\title{
Relacje międzygrupowe na tle wielkiego projektu przemysłowego, na przykładzie rozbudowy Elektrowni Opole ${ }^{1}$
}

\section{Abstract \\ Inter-group Relations and Large Industrial Project. The Case of Opole Power Plant Development}

The article presents the analysis of dynamics of ethnic relations in a small commune near Opole. At the background of the relations are social processes launched by the expansion of the Opole Power Plant. In line with previous studies on the impact of large industrial investments on the local communities and the work on inter-ethnical relations in the studied municipality, I presumed that the current expansion may affect mutual intergroup relations, because they remain tense from at least the end of the Second World War. Although for more than ten years there has been a significant progress in building a sense of local community. This process has now been disturbed not only by the expansion of the power plant, but also by the imposed change of the municipality's borders, as a result of which the power plant is no longer within the limits of the municipality. The battle to maintain the existing borders revealed that "ethnicity" can still be a living differentiating element, but also a building community factor.

Keywords: local community, ethnicity, social conflict.

1 Artykuł powstał w ramach grantu badawczego pod tytułem Konflikt, napięcie, współpraca. Studium interakcji pomiędzy Elektrowniq Opole a społecznością gminy Dobrzeń Wielki. Projekt został sfinansowany ze środków Narodowego Centrum Nauki przyznanych na podstawie decyzji numer DEC-2013/11/B/HS3/03895. 
Jedna z wczesnych monografii dotyczących Dobrzenia Wielkiego została poświęcona badaniom nad skutkami industrializacji dla społeczności lokalnej. Jej autorka, Anna Olszewska, stwierdziła we wniosku ze swoich długotrwałych badań terenowych, że industrializacja nie musi z konieczności wywoływać zmian przewracających dotychczasowy porządek społeczny czy negatywnie wpływać na dominujący w społeczności system wartości (Olszewska 1969). Obecna rozbudowa Elektrowni Opole, która stała się obiektem badań w projekcie będącym podstawą niniejszego artykułu, nie tylko potwierdza tezę Olszewskiej, ale pokazuje także, iż wielki projekt przemysłowy może wręcz te wartości wzmacniać, co w społeczności o złożonej identyfikacji narodowej wciąż może być potencjalnym źródłem napięć. Prace antropologów ekonomicznych wskazują też, że projekty modernizacyjne, związane często $\mathrm{z}$ industrializacją, stanowią źródło klasowego konfliktu między machiną biurokratyczną a społecznością, której plany biurokratyczne dotyczą (Hann, Hart 2015: 127; por. też: Graeber 2016). Wydarzenia, które przypadkowo stały się tłem prowadzonych przeze mnie od 2015 roku badań w Dobrzeniu Wielkim, czyli wymuszona wbrew lokalnej społeczności zmiana granic gminy, odsłoniły także te i inne wymiary lokalnych napięć. Etniczność, klasa i polityka splotły się tu w nierozerwalnym węźle, który stanowił ważne źródło definicji sytuacji i społecznych na nią reakcji.

Dobrzeń Wielki jest niewielką gminą zamieszkaną przez kilka dużych grup typu „my”. Badania na jej terenie, które zaprojektowano początkowo jako przekrojowe, dotyczące kwestii poruszanych we wcześniejszych opracowaniach socjologicznych na temat gminy (m.in.: Ossowski 1947 [1984]; Nowakowski 1957, 1960; Olszewska 1969), zostały zogniskowane wokół kwestii wytwarzania relacji międzygrupowych, rozumianych też oddolnie, przez różnych aktorów zaangażowanych w ich wytwarzanie i podtrzymywanie, jako relacji międzyetnicznych.

Relacje międzygrupowe na Opolszczyźnie były przedmiotem wnikliwych badań wielu badaczy, choć niewątpliwie najwięcej uwagi regionowi poświęcili uczeni z Instytutu Śląskiego w Opolu, a szczególnie wartościowym źródłem danych i interpretacji pozostaje periodyk Instytutu ukazujący się od końca lat 50. zatytułowany "Studia Śląskie”. W ramach zainteresowań naukowych pracowników Instytutu znalazły się także między innymi relacje międzyetniczne i międzygrupowe na terenie gminy Dobrzeń Wielki. Istotnym faktem dla antropologa podejmującego badania oddolnych procesów konstruowania i podtrzymywania granic międzygrupowych na terenie gminy jest to, iż podobna do antropologicznej perspektywa badań dominuje od pierwszych powojennych badań w Dobrzeniu Stanisława Ossowskiego (badania z 1945 roku), po nowsze prace socjologów z Instytutu Śląskiego (por. np. Frysztacki 1998). Badania Stanisława Ossowskiego, które pokazały przede wszystkim znaczenie więzi regionalnej, swojskości, jako źródła tożsamości zbiorowej sytuowanej powyżej więzi narodowej w Giełczynie (pod taką nazwą ukrył Ossowski Dobrzeń Wielki), do dziś uchodzą za wyjątkowo trafne. Badania te zostały podjęte już latem 1945, a kontynuowane były jeszcze 
w 1947, tym razem z asystentem Stefanem Nowakowskim, który z kolei w 1957 roku powrócił do Dobrzenia z własnymi studentami, między innymi Anną Olszewską (Sołdra-Gwiżdż 2010). Zarówno Nowakowski, jak i Olszewska przedstawili własne opracowania dotyczące zmian, jakie zaszły od czasu badań Ossowskiego w społeczności Dobrzenia w zakresie kształtowania się społeczności lokalnej. Stefan Nowakowski wskazywał na zasadniczą rolę czynników klasowych w procesach więziotwórczych i konfliktach grupowych, natomiast Anna Olszewska starała się wymienić pozytywne skutki industrializacji dla kształtowania się więzi lokalnych, w innej pracy natomiast wskazywała na pozytywne skutki małżeństw mieszanych i negatywne - emigracji (Olszewska-Ładykowa, Żygulski 1959).

Na szczególną uwagę zasługują nowsze prace traktujące o relacjach międzygrupowych w regionie opolskim, między innymi praca Marii Szmeji (1997), która zmagała się ze znalezieniem właściwego pojęcia mogącego dobrze określić stan nie pełnej integracji społeczności, nie otwartego, lecz podskórnego reprodukowania różnic, które połączone jest z poczuciem dyskryminacji i doznanych krzywd w obu grupach: autochtonicznej (silniejszej) i napływowej. Z kolei praca zbiorowa pod redakcją Krzysztofa Frysztackiego (1998) osadzała w planie historycznym stosunki międzygrupowe, wskazywała na rolę instytucji (dom kultury, szkoła, parafia) w kształtowaniu tych relacji, wagę stereotypów, wzorów życia i wartości. Warto zaznaczyć, że wszystkie dotychczas wymienione prace unikają esencjalizowania etniczności. Esencjalizujące kategorie etniczne, z dominującą opozycją „mniejszość niemiecka/Niemcy” - „Polacy”, pojawiają się przede wszystkim w opracowaniach popularnych, wypowiedziach potocznych i publicystycznych, natomiast autorzy znający społeczną i kulturową sytuację gminy takich ujęć nie stosują.

Problemy społeczne związane z budową, a obecnie rozbudową Elektrowni Opole również mają swoją bogatą literaturę (por. np.: Kokot 1988, Szmeja 1988; Woźniacki 1988; Biela 1993; Sobek 1993; Berlińska 1995; Malarski 1995; Rauziński 1995; Domański 1997; Kałuża 2003; Czech 2009; Sołdra-Gwiżdż 2009), która posłużyła jako fundament konstrukcji prowadzonych przeze mnie badań2. Projekt w zakresie moich badań miał na celu analizę i wyjaśnienie dynamiki relacji etnicznych w kontekście procesów społecznych uruchomionych przez rozbudowę Elektrowni Opole. Zakładałem, że rozbudowa może mieć wpływ na wzajemne relacje międzygrupowe w gminie Dobrzeń Wielki, ponieważ te od co najmniej końca II wojny światowej pozostają napięte (na co też wskazuje bogata w tym

2 Ludność miejscowa postrzegała budowę między innymi jako element rozbijania lokalnej spójności i kolejną składową osłabiania mniejszości niemieckiej w stosunku do ludności napływowej, dotkliwie odczuwano utratę ziemi, a niedogodności codzienne związane z ogromnym placem budowy uznawano za rodzaj ofiary/daru, który będzie wymagał odwzajemnienia, jednak szczególne problemy generowała obecność przyjezdnych robotników, których zachowania na budowie i poza nią odbiegały zarówno od lokalnego etosu pracy, jak i lokalnych norm współżycia społecznego (postrzeganych w kategoriach fundamentalnej różnicy „tutejsi-obcy”). 
zakresie literatura). Gmina zamieszkana jest przez ludność autochtoniczną oraz ludność napływową. Ta ostatnia znalazła się w gminie Dobrzeń Wieki w ramach kilku fal osadniczych. Pierwsza powojenna fala przywiodła do Dobrzenia ludność z dawnej Polski wschodniej, zajętej przez ZSRR. Przesiedleńcy tworzyli w obrębie gminy zwarte osadnictwo - w wysiedlonej wsi Brzezie-Finkelstein - w przeciwieństwie do ludności z innych rejonów Polski. Kolejne fale osadnicze związane były z osadnictwem podmiejskim, z bliskością Opola, a następnie, od lat 70. do lat 90. z budową Elektrowni Opole. Ponieważ debata nad przyczynami napięć ma ogromną literaturę, zarówno naukową, jak i ustną, czyli swoisty lokalny folklor, odwołam się jedynie do fragmentu artykułu Danuty Berlińskiej, w którym autorka celnie tłumaczy powody względnej konserwacji zamkniętego układu lokalnych identyfikacji i wzajemnych relacji:

\begin{abstract}
Przegrana wojna przyniosła kryzys tożsamości Niemców i poszukiwanie nowych identyfikacji przez Ślązaków. W konfrontacji z Polakami Ślązacy przekonywali się, że choć przed wojną nie byli dość niemieccy, aby byli powszechnie uważani za Niemców, to po wojnie ich odmienność kulturowa wyrażająca się m.in. w „skażonej” niemczyzną gwarze dyskwalifikowała ich jako Polaków i sprawiała, że jako „niepewny element” ciągle byli narażeni na praktyki dyskryminacyjne. W wyniku presji polonizacyjnej (wprowadzono m.in. zakaz posługiwania się językiem niemieckim) i praktyk dyskryminacyjnych pogłębiał się proces izolacjonizmu Ślązaków od Polaków i zwiększało się subiektywne poczucie bliskości wobec Niemców. Procesy te przyczyniły się do kolejnych fal emigracji do RFN. Ci, którzy pozostali, zastosowali izolacjonizm jako mechanizm obronny, wyrażający się w niechęci do wychodzenia poza społeczność lokalną, ograniczeniem kontaktów instytucjonalnych do koniecznego minimum, brakiem akceptacji małżeństw mieszanych, niskimi aspiracjami edukacyjnymi, utrzymywaniem się negatywnych stereotypów i uprzedzeń, wzmacnianych przez pogłębiające się trudności codziennego życia wskutek nieefektywnej gospodarki. Dochodziło również do konfliktów, które realizowały się już nie na poziomie władza - nowy obywatel, ale na poziomie międzyludzkich kontaktów w ramach społeczności lokalnych (Berlińska 1998b: 34).
\end{abstract}

Relacje międzygrupowe, oparte na lokalnej wiedzy na temat wyżej zarysowanego procesu, powodowały, że lokalne więzi, aż do końca lat 90., rozwijały się nie w poprzek lokalnych podziałów, co mogłoby skutkować wytworzeniem się społeczności lokalnej o zasięgu regionalnym (gminnym), ale w obrębie węższych kręgów „swojskości”, raczej konserwując podziały, niż je znosząc. Jednak kiedy podjęliśmy wstępne badania już w 2005 roku, wielu informatorów podkreślało, że dawne podziały przestają być znaczącym elementem relacji międzygrupowych, w szczególności bardzo często podkreślano fakt małżeństw „mieszanych”, bliskich więzi między młodymi ludźmi, którzy między innymi uczęszczają do tych samych szkół, wspólnie migrują w poszukiwaniu pracy. Można było odnieść wrażenie, że dopiero w ostatnich latach kształtuje się w gminie społeczność lokalna.

W tym kontekście ważnym czynnikiem mogącym naruszyć ten proces, a zarazem przesłanką do podjęcia badań, wydała się rozbudowa Elektrowni Opole, ponieważ w tym ogromnym przedsięwzięciu miało wziąć udział ok. 4000 robotników (wobec 15 tys. mieszkańców całej gminy), niekoniecznie rekrutujących 
się z pracowników lokalnych, nieznających lokalnych "gramatyk” wzajemnych zachowań. Inną przesłanką do podjęcia badań były wyniki wcześniejszych prac socjologicznych na terenie gminy Dobrzeń Wielki, dotyczących społecznego odbioru najpierw budowy, a potem rozbudowy Elektrowni Opole, które wskazywały, iż obu procesom towarzyszyły obawy o naruszenie wyłaniającego się mozolnie miejscowego ładu (por. Sołdra-Gwiżdż 2009: 47-48).

\section{Metodyka badań i założenia teoretyczne}

W celu poddania analizie tytułowej dynamiki relacji międzygrupowych, w latach 2015-2018 przeprowadzono etnograficzne badania terenowe na terenie gminy, nakierowane na pozyskanie wiedzy na temat oddolnych doświadczeń związanych $\mathrm{z}$ rozbudową, w szczególności na wyłonienie skryptów kulturowych ${ }^{3}$ kierujących tymi doświadczeniami, ze szczególnym uwzględnieniem węzłów semantycznych, których składnikami są „inni” i relacje z „innymi”.

Uznałem, że najskuteczniejszym narzędziem pozwalającym na uzyskanie wiedzy w zakresie znaczących dla społeczności gminy procesów związanych z rozbudową Elektrowni Opole, w szczególności tych, które oddziałują na lokalne relacje międzygrupowe, będzie powiązanie powtarzanych wywiadów ukierunkowanych $\mathrm{w}$ formie rozmów $\mathrm{z}$ wybranymi mieszkańcami gminy $\mathrm{z}$ obserwacją praktyk społecznych, pracą nad danymi zastanymi i monitoringiem/obserwacją treści dostępnych w sferze publicznej odnoszących się do interesujących mnie relacji.

Dlaczego wywiad w formie rozmów, czyli bez dyktafonu i odpytywania informatorów z przygotowanego wcześniej kwestionariusza? Otóż uznałem, iż w warunkach badanego miejsca, przy całej złożoności lokalnej sytuacji, ale też wiedząc o lokalnych doświadczeniach z badaniami ankietowymi, które stosunkowo często realizowane były w gminie, wstępnym warunkiem uzyskania wiedzy o relacjach wzajemnych jest mniej formalny sposób interakcji, pozwalający również badaczowi nauczyć się lokalnych idiolektów zachowań i właściwych w tym miejscu reguł konwersacji. Miałem czas i nadzieję, że ten sposób zneutralizuje efekt ankietowego dystansowania się informatorów od własnych wypowiedzi, które często stają się reprezentacjami wyobrażonych treści, właściwych dla danej sytuacji kontaktu $\mathrm{z}$,profesjonalnym-obcym” oraz zadanym przez niego trybem kontaktu, a sam szybciej dowiem się, jakie pytania w tym miejscu, w odniesieniu do problemu badawczego, powinienem zadawać. Zasób problemów, poprzez które można było dotrzeć do interesujących mnie kwestii, poza wstępnym etapem badań, na którym sporządziłem kwestionariusz (od początku miał być jedynie nieujawnianym

3 Skrypt kulturowy jest odmianą skryptu poznawczego i stanowi kulturowy program działań (obejmujących również ramy interpretacyjne / modele kulturowe) skorelowany z konkretnymi, typowymi sytuacjami, który umożliwia szybkie rozpoznanie sytuacji i reakcję na nią. W tym znaczeniu pojęcie to jest często używane na gruncie nauk społecznych. 
informatorom przewodnikiem dla mnie), rozwijał się zatem $\mathrm{w}$ trakcie badań, stale oscylując wokół zasadniczego problemu badawczego. Miałem również na względzie fakt, iż potoczna wiedza, będąca znaczącą częścią interesujących mnie oddolnych doświadczeń, nie ma charakteru analitycznego, nie jest w pełni przekładalna na formy dyskursywne, dlatego nie oczekiwałem, że będzie w całości zawarta $\mathrm{w}$ wypowiedziach informatorów lub że sama treść wypowiedzi informatorów może być wyłącznym kluczem jej rekonstrukcji (por. np.: Bloch 1998:11).

Rozmowy prowadzone były wokół kilku zasadniczych osi tematycznych, które ewokowały zagadnienia szczegółowe. Prowadziłem zatem rozmowy/wywiady zogniskowane na pamięci budowy i historii obecnej rozbudowy elektrowni wśród różnych grup ludności; ocenie obecności różnic grupowych w przestrzeni publicznej, prywatnej i półprywatnej; stosunku do i obecności nowo przybyłych pracowników budowy w przestrzeni publicznej oraz ich relacji/interakcji z ludnością miejscową; historii relacji wzajemnych na terenie gminy; stereotypów wzajemnych; autostereotypów grup mieszkańców gminy; stosunku do małżeństw mieszanych czy sfer życia, w których obecność różnic międzygrupowych wydaje się niewątpliwa. Wypowiedzi zostały odniesione do praktyk społecznych (takich jak np. podnoszony we wcześniejszych opracowaniach problem akceptacji małżeństw „mieszanych” i praktyk ich zawierania), które są ważnym wskaźnikiem relacji międzygrupowych. Stąd ważną składową danych są te pochodzące z obserwacji zarówno zachowań, jak i znaków w przestrzeni publicznej i domowej, uzupełniane danymi z dyskursu publicznego (lokalna prasa, biuletyny informacyjne, lokalne portale internetowe, fora internetowe itp.).

Wybór informatorów był od strony zamiaru stosunkowo łatwy - chodziło o osoby, które w stosunku do elektrowni mają różny stopień zależności/niezależności oraz zajmują różne pozycje w lokalnej mozaice różnorodności grup. Od strony praktycznej wskazanie takich osób, dotarcie do nich i uzyskanie zgody na rozmowę nie zawsze było łatwe, często kończyło się niepowodzeniem, choć z czasem rozrastające się sieci znajomości oraz dostępna publicznie informacja na temat prowadzonych w Dobrzeniu badań przedstawiana przez miejscowy portal informacyjny (Grupa Lokalna) zmieniły tę sytuację. W rezultacie udało się pozyskać znaczący korpus danych terenowych, który znacznie przekroczył planowane w projekcie 30 wywiadów.

Fundamentem teoretycznym, na którym oparły się analizy tytułowej problematyki, były wciąż aktualne generalizacje Fredricka Bartha dotyczące dynamiki relacji wewnątrz grup etnicznych i między nimi (Barth 1969), a także konstruowania/zanikania granicy między grupami. Ważnym punktem wyjścia było założenie o procesualnym, oddolnym definiowaniu granic międzyetnicznych jako podstawie stosunku i praktyk w stosunku do innych, oraz płynnym, bo konstruowanym społecznie (i dwustronnie), ich charakterze. Konstruowanie w istocie społecznych granic (etniczność jest strategiczną reakcją na warunki społeczne) jest procesem, w który zaangażowanych jest wiele instytucji niekoniecznie związanych bezpo- 
średnio z daną lokalnością (np. instytucji prawnych, procedur biurokratycznych). Od razu dodam, że podobna perspektywa była obecna już w badaniach socjologicznych dotyczących problematyki relacji międzygrupowych w tym rejonie (por. np. Berlińska 1998a).

\section{Wyniki badań}

Badaniem objętych zostało kilka miejscowości: Borki, Brzezie, Czarnowąsy, Dobrzeń Wielki, Kup, Świerkle i Chróścice. Moimi rozmówcami byli drobni przedsiębiorcy, działacze samorządowi i mniejszości niemieckiej, robotnicy pracujący przy rozbudowie (zarówno ci, którzy mieszkali w hotelu robotniczym w Brzeziu przy elektrowni, jak i rozproszeni po lokalnych kwaterach na terenie gminy) oraz mieszkańcy gminy, z którymi w różnych okolicznościach udało mi się rozmawiać raz lub kilkukrotnie. Jednym $\mathrm{z}$ centralnych zagadnień, które stało się osią wokół której ogniskowałem pytania, była sfera widocznej, zauważalnej publicznie aktywności różnych grup i relacji miedzy nimi. Szybko okazało się, iż problem relacji międzygrupowych na terenie gminy w kontekście rozbudowy Elektrowni Opole uruchamia narracje niekoniecznie związane z samą budową czy elektrownią jako zakładem pracy.

Podstawową ramą odniesienia dla informatorów była bowiem dynamika relacji w planie historycznym między miejscowymi Ślązakami a napływowymi Polakami. To w tym planie umieszczane są kwestie budowy i rozbudowy elektrowni. Chcę wyraźnie tu zaznaczyć, iż moim zamiarem nie było siłowe kierowanie rozmowami tak, aby rozmówca nie wychodził poza zadane przeze mnie ramy (związane z rozbudową elektrowni), ale aby mógł swobodnie wypowiedzieć się na temat relacji międzygrupowych $\mathrm{w}$ gminie. $\mathrm{W}$ ten sposób rozbudowa mogła, ale nie musiała pojawiać się jako znaczący kontekst tych relacji i faktycznie marginalnie wspominano o pracownikach rozbudowy czy fakcie prowadzenia tak dużej inwestycji, co moim zdaniem jest ważnym wskaźnikiem roli przypisywanej tym faktom w odniesieniu do relacji międzygrupowych.

Wielokrotnie miałem okazję rozmawiać z pracownikami rozbudowywanej elektrowni różnego szczebla. Ci, którzy pracują w zespołach wykonujących pojedyncze zadania, przyznają, że mają bardzo mały kontakt z miejscową ludnością, ograniczający się do sklepów i kwater. Faktycznie rozmowy po pracy, których często byłem biernym świadkiem lub uczestnikiem, mieszkając w kwaterach, w których również pomieszkiwali pracownicy rozbudowy (w Brzeziu, Chróścicach, Dobrzeniu Małym), nie dotyczyły miejscowych, ale na ogół spraw zadań, kolejnych zleceń, doraźnego zaopatrzenia i tym podobnych kwestii. Niemniej uwagi na temat miejsca pobytu też się pojawiały. Dotyczyły wtedy wyglądu domów i ich otoczenia czy faktu, iż wiele domów jest niezamieszkanych (w szczególności dotyczyło to miejscowości Borki, gdzie wielu robotników robi zakupy). W rozmowie 
z pracownikami pochodzącymi z centralnej Polski (w Brzeziu) pojawił się motyw wyjątkowej czystości wokół domów oraz „niemieckiego porządku” czy „niemieckiego stylu okien (i firan)” - reprezentacje „niemieckości” regionu, i potocznej wiedzy na temat tego faktu, są zróżnicowane wśród pracowników rozbudowy elektrowni. Dla robotników tymczasowych obejmują jedynie widoczną, materialną tkankę, i to bez względu na rzeczywiste obserwacje, na przykład o widocznej różnicy usłyszałem w Brzeziu, które jest zamieszkane przez „repatriantów” ze wschodu i według miejscowych standardów odbiega od ideału śląskiego porządku. Robotnicy ci, pochodzący z województwa świętokrzyskiego na weekend wyjeżdżali z gminy, a ich codzienny kontakt z miejscowym otoczeniem ograniczał się do zakupów w dyskontach w miejscowości Borki. Ci, którzy nie wracają na weekendy do domu, uczestniczą niekiedy w festynach, bywają nad jeziorkiem Balaton (popularne miejsce spędzania wolnego czasu w Dobrzeniu Wielkim) czy na niedzielnej mszy, ale nie nawiązują kontaktów z miejscowymi ani nie czują, aby miejscowi o taki kontakt zabiegali. Weekendowe wyjazdy do domów nie sprzyjają nie tylko nawiązywaniu kontaktów, ale też zbudowaniu wiedzy o miejscu, w którym się czasowo przebywa. Wielu robotników, szczególnie tych, którzy rozlokowani są w hotelach robotniczych przy elektrowni, nie interesuje się w ogóle miejscowymi realiami, tworząc swój własny mikroświat codzienności odseparowanej od lokalności.

Prominentni przedstawiciele zarówno inwestora, wykonawcy, jak i gminy (osoby zaangażowane w proces decyzyjny dotyczący rozbudowy Elektrowni Opole) w rozmowach ze mną podkreślali, że zadbali o minimalizację wpływu rozbudowy na warunki życia mieszkańców, minimalizację ryzyka związanego $\mathrm{z}$ wpływem na lokalne środowisko (obniżenie wód gruntowych, zanieczyszczenie powietrza), a jedynym widocznym i mogącym być źródłem niezadowolenia skutkiem rozbudowy, jaki rysował się z rozmów, była konieczność wykupienia gruntów i domów w Brzeziu oraz niszczenie dróg w wyniku operowania ciężkiego sprzętu (też dotyczy to głównie wsi Brzezie). Podkreślana dbałość o nienaruszanie miejscowego ładu ma swoje źródła $\mathrm{w}$ relatywnie niedawnym i dobrze pamiętanym, znanym rozmówcom konflikcie związanym $\mathrm{z}$ budową elektrowni oraz padających wówczas deklaracjach neutralizujących dostrzegane przez mieszkańców ryzyka: obiecano, poza miejscami pracy, darmowe ciepło i o połowę tańszy prąd, a potransformacyjna rzeczywistość przyniosła dodatkowy zysk w postaci części podatków, które zasiliły znacząco budżet gminy (por. też: Czech 2009). Elektrownia realizowała wzorowo program „społecznej odpowiedzialności biznesu”, starając się usytuować w obrębie „swojskiego”, lokalnego świata. Jednak wobec lokalnych wzorów wartości uprzywilejowujących pracę, stabilizację oraz samorządność budowa elektrowni naruszała dwie ostatnie, zatem z „lokalnego punktu widzenia" była inwestycją wysokiego ryzyka (por. np.: Douglas 1992). Kadra menadżerska obecna w gminie na etapie budowy dobrze zna miejscowe warunki społeczne i zasięg oddziaływania inwestycji na gminę, a elektrownia monitoro- 
wała je przy pomocy zlecanych badań (np. Rosik-Dulewska, Kusz 2009), zatem w neutralizacji obecnego ryzyka starano się uwzględnić aspekt społeczny. Jak pokazuje niedawna historia niewielkiego oporu wobec elektrowni i jego szybkie wygaśnięcie, zrobiono to skutecznie.

Niemniej dopiero wydarzenia związane ze zmianą granic gminy i przyłączeniem elektrowni do Opola pokazały, ze wypracowana latami „swojskość” wielkiego obiektu przemysłowego oraz „społeczna odpowiedzialność biznesu” są kruchą podstawą relacji wzajemnych ze społecznością gminy. Od momentu włączenia elektrowni w granice administracyjne Opola notowałem więcej głosów krytycznych z nią związanych, dotyczących między innymi realnego braku wpływu budowy i rozbudowy na polepszenie sytuacji na lokalnym rynku pracy, problemów wywołanych obniżeniem stanu wód gruntowych, zapyleniem związanym z obecnością ciężkiego sprzętu. „Wspólne dobro”, jakim miała być inwestycja, najwyraźniej staje się dla mieszkańców okrojonej gminy mniej wspólne. Oczywiście podobne reakcje i ujawnienie realnych fundamentów tego, czym jest „społeczna odpowiedzialność biznesu", w antropologii nie jest niczym niespodziewanym. Przykładowo Dinah Rajak pokazała na podstawie własnych badań nad spółkami wydobywczymi platyny w RPA, że tak zwana społeczna odpowiedzialność biznesu jest tylko pozornie szlachetnym partnerstwem wielkiego przemysłu i społeczności lokalnych mającym na celu harmonijny, zrównoważony rozwój. Wielkie inwestycje przedstawiane są przez polityków i inwestorów jako „dar”, który wymaga odwzajemnienia w postaci lojalności ze strony obdarowanych. Ponieważ społeczność jest tu słabszym ogniwem, relacje pozostają asymetryczne, a lojalność silniejszego - iluzoryczna (Rajak 2009; por. też: Dolan, Rajak 2016), co w sytuacjach kryzysowych, takich jak ta w Dobrzeniu wywołana zmianą granic, ujawnia się z całą wyrazistością.

Niemniej we wszystkich prowadzonych wywiadach i rozmowach wskazywano, iż istotne okoliczności kształtujące relacje międzygrupowe na terenie gminy wykraczają poza fakt budowy czy rozbudowy elektrowni. Zdaniem rdzennych mieszkańców gminy, taką okolicznością była dyskryminacja miejscowych Ślązaków w przestrzeni publicznej, skutkująca zepchnięciem lokalności do sfery prywatnej i zamkniętego kręgu znajomych (wypowiedzi w tym duchu można też odsłuchać na stronie Archiwum Historii Mówionej: http://e-historie.pl/audycje-15,1.html). Różny był stopień głębokości przywoływanej w tym kontekście wiedzy historycznej - od średniowiecznych czesko-polskich początków Śląska, przez hitlerowskie Niemcy, po, najczęściej przywoływany, czas po II wojnie światowej, kiedy to lokalna władza została oddana „niemiejscowym”, a języki lokalne, zarówno gwara śląska, jak i niemiecki (określane często jako „swoje”), rugowane były z przestrzeni publicznej (przed II wojną światową śląski z podobnych powodów, jako odmiana języka polskiego, był zakazany).

Jeden z moich informatorów, miejscowy, którego rodzina wywodzi się z Kup, nakreślił długą linię pogmatwanej, choć dobrze udokumentowanej historii włas- 
nej rodziny, w której wątek „niesprawiedliwości dziejowej”, odbierania majątku, konieczności wyboru narodowości, aby majątek zachować, stanowił zasadniczą część opowieści, która była złożoną odpowiedzią na pytanie o miejscowe relacje międzygrupowe. Bardzo często miałem zresztą okazję usłyszeć, że miejscowych „wyzywano”, „piętnowano” jako „Niemców”, „szwabów”, „hanysów”, że „wyśmiewano" język miejscowy (gwarę śląską z dużą liczbą niemieckich naleciałości), co szczególnie boleśnie odczuwano w szkole. Należy jednak zaznaczyć, iż zarówno ludność napływowa, jak i miejscowi posługiwali się wzajemnie określeniami pogardliwymi - ci ostatni na pierwszych mówili „Chadziaje/Chaziaje”. Wstyd towarzyszący posługiwaniu się językiem lokalnym w okresie PRL wskazywany był też wielokrotnie $\mathrm{w}$ moich badaniach jako czynnik przyspieszający proces porzucania lokalnej tożsamości. Świadomość nie tylko odrębności gwary, ale także procesu kształtowania się tej odmiany języka jest silna i nie raz miałem okazję wysłuchać miniwykładów na temat wpływów niemieckiego i czeskiego (z przykładami konkretnych zapożyczeń) na gwarę śląską.

Początek lat 90. to swoboda tworzenia oddolnych stowarzyszeń, objęcie władzy lokalnej przez miejscowych i możliwość włączenia w większym wymiarze języka niemieckiego do nauczania w szkołach. Informatorzy zauważyli, iż w przestrzeni publicznej zaczęło działać Towarzystwo Społeczno-Kulturalne Niemców na Śląsku Opolskim, organizując imprezy promujące lokalną kulturę oraz skutecznie włączając się w lokalną politykę. Jednak, jak podkreślają, to już przeszłość - dziś działania TSKN są niezauważalne. Informatorzy nie potrafią w większości wskazać uroczystości i widocznych działań organizacji, twierdzą też, że nie ma obecnie ekskluzywizmu w organizacji wszelkich uroczystości na terenie gminy. Co ciekawe, sama kategoria „mniejszości niemieckiej”, ważna dla miejscowej ludności na początku lat 90., traci na wyrazistości nawet wśród prominentnych przedstawicieli politycznej reprezentacji mniejszości niemieckiej. W czasie poszukiwania kontaktu z miejscowymi działaczami mniejszości niemieckiej zdarzyło mi się, iż ważny reprezentant mniejszości odmówił spotkania, tłumacząc, że musiałby szczerze powiedzieć coś, co mogłoby nie spodobać się innym miejscowym. Z kolei inny reprezentant i działacz mniejszości niemieckiej na samym początku naszego spotkania zaznaczył, że choć pełni znaczące funkcje, nie określiłby się jako wyłącznie Niemiec, że jest po prostu miejscowym Ślązakiem-Niemcem, wskazując jednocześnie, że na terenie gminy do mniejszości przynależą faktyczni potomkowie Niemców osiedlonych tu na długo przed II wojną światową, ale jest ich zaledwie garstka, a większość to ludność miejscowa, autochtoni, którzy „dla Niemców nie są i nie byli nigdy wystarczająco niemieccy, dla Polaków za to byli zbyt niemieccy”. Zatem tożsamość autochtonów jest „typowo pograniczna” - teoria społeczna zgadza się w tym punkcie $\mathrm{z}$ wiedzą lokalną. Powodowała ona podobny, graniczny status ludności miejscowej, trudności z wpasowaniem się w precyzyjne kategorie czy rubryki, które wraz ze spisami ludności miały definiować miejscową tożsamość. Jeden z informatorów wprost zwrócił uwagę na „ideologię 
i politykę państwa narodowego" wskazującą na wyższość szerokiej narodowej tożsamości względem „tutejszości” jako na tę, która zarówno przed II wojną światową, jak i po niej potęgowała poczucie marginalizacji miejscowej ludności oraz budziła napięcia wewnątrz społeczności.

Jak w żadnym innym miejscu, w którym miałem okazję prowadzić badania, dyskutując kwestie tożsamości, przywoływano niekiedy kategorię „słowiańskości” - do tej kwestii powrócę, omawiając wyniki. Ogólnie większość informatorów deklaruje, że odrębność grup manifestuje się jedynie w sferze życia rodzinnego, gdzie oprócz możliwości komunikowania się w „swoim” języku ${ }^{4}$ obchodzi się rodzinne święta (np. urodziny, Dzień Matki - w innym dniu niż „w Polsce”). Deklaruje także, iż w zakresie stosunków wzajemnych obserwuje się duże zmiany, szczególnie nasilone w ostatniej dekadzie. Duża liczba ludności napływowej, coraz częstsze małżeństwa mieszane, wspólne instytucje (szkoła, urzędy, praca, imprezy i uczestnictwo $\mathrm{w}$ wielu formach zorganizowanego przez gminny ośrodek kultury życia „kulturalnego”) powodują, że relacje wzajemne postrzegane są jako „coraz lepsze”, „zgodne”, oparte na współpracy. Miejscowi Ślązacy pozytywnie oceniają fakt „asymilacji” ludności napływowej, poszanowania dla miejscowego sposobu życia, porządku, jednocześnie panuje przekonanie o zanikaniu gwary i kultury śląskiej.

Szczególną uwagę w kontekście tak sytuowanych obecnie relacji przykuwa fakt, iż dwujęzyczne tablice nazw miejscowości bywają od czasu do czasu zamalowywane. Problem jest przez wielu informatorów bagatelizowany, a dotyczące go wypowiedzi można streścić $\mathrm{w}$ formacie: „nie należy do tego przywiązywać większej wagi". Jednocześnie jest to temat, który odsyła do wielu kwestii istotnych dla zrozumienia dynamiki relacji międzygrupowych. Niektórzy, a szczególnie odnosi się to do informatorów będących autochtonami, podkreślają, że tablice nie stanowią obecnie problemu, a zamalowywanie jest sprawką „przekupionej młodzieży”, „dzieciaków”, chuliganów, ewentualnie „bandy” lub „narodowców”. Jednak od 2009 roku, czyli momentu wprowadzenia tablic dwujęzycznych, w gminie zamalowywanie jest coraz rzadsze. Pytanie o problem wywołuje niekiedy silne reakcje emocjonalne: jeden $\mathrm{z}$ informatorów stwierdził, że jest to świadome politycznie działanie obliczone na antagonizowanie Polaków i Niemców (Ślązaków), inny, że w ten sposób manifestuje się „kompleks niższości” („zazdrość”, „Złość”) przyjezdnych względem ludności autochtonicznej.

Nie-Ślązacy zwracają uwagę, iż to mniejszość niemiecka „wywalczyła” prawo do tablic, wprawdzie część informatorów ma świadomość, iż prawo Unii Europejskiej gwarantuje taką możliwość (jeden z informatorów nawet podkreślił „europejskość" rozwiązania, co napawało go dumą), ale jednocześnie traktuje tablice jako „niekonieczne”, „zbędne” podkreślanie różnic, nawet w sensie marnotrawienia publicznych pieniędzy na ich renowację. Przywoływano w tym kontekście

4 Dialekt śląski, jak deklarowali moi śląscy rozmówcy, dominuje jako język komunikacji domowej, co potwierdzają dane ze spisów powszechnych z 2002 i 2011 roku (Biernacka, Kunicka 2013). 
fakt, że przecież „tu” wszyscy „mówią po polsku, więc po co tablice”. Część uważa, iż są one świadectwem nierównego traktowania Polaków i Niemców - w Polsce Niemcy mają „swoje” tablice, w Niemczech Polacy podobnych nie mają. Stwierdzenie, które streszcza częste kończenie tematu tablic, jest znaczące: „mi to specjalnie nie przeszkadza, powiem tak" - stosowane formuły wskazują, że problem tablic reprezentuje występujące różnice, choć często kwitowane stwierdzeniem, że „już było gorzej”. Jeszcze inni wskazali na ich zdaniem naganny tryb wprowadzania tablic, bez konsultacji społecznych - w tych narracjach władza opowiedziała się wyraźnie po jednej ze stron i ten fakt może prowokować niezadowolenie, którego manifestacją jest zamalowywanie tablic. Jako kontrprzykład wskazuje się sąsiednią gminę Popielów, gdzie doszło do „referendum” i obecnie, zdaniem informatorów, nie ma podobnego problemu.

Kolejnym zagadnieniem, które ogniskowało problematykę relacji wzajemnych w kontekście rozbudowy, były publiczne wydarzenia, lokalnie organizowane imprezy otwarte. Wielu informatorów zwracało uwagę, iż mieli obawy o przebieg imprez, gdy pojawią się na nich robotnicy pracujący przy rozbudowie elektrowni. Obawiano się pijaństwa, zaczepek - „pijaństwo” jako znak różnicy między swoimi i obcymi jest przywoływane w wielu kontekstach, również kiedy jest mowa o ludności napływowej. Jednak zgodnie podkreśla się, że obawy się nie potwierdziły. Niemniej sam temat również okazał się jednym z węzłów uwyraźniających istniejące podziały i choć nie są one związane z rozbudową, to stanowią ważny kontekst dla wszelkich kategoryzacji i semantycznych przyporządkowań konkretnych grup i działań, co może rzucać światło na zagadnienia związane z rozbudową w sposób niebezpośredni, dlatego ten wątek w badaniach był podjęty. W materiałach $\mathrm{z}$ badań powtarza się motyw „niemieckiego wzoru” imprez, zarówno tych masowych, jak i mniejszych, prywatnych i półprywatnych w rodzaju urodzin (Geburstag) organizowanych w zakładach pracy. W kilku przypadkach odnotowałem, iż nie-Ślązacy uznali, że imprezom towarzyszy nieformalny podział, że wciąż istnieją kręgi przynależności oparte na „czasie zamieszkiwania w gminie” (np. nierówny udział w organizacji dożynek, z preferencją dla „autochtonów”, którzy „nie dopuszczają napływowych, chadziajów"; w tej kategorii znalazła się także msza w języku niemieckim). Równocześnie wielu informatorów podkreślało efekt integracyjny imprez masowych (festynów letnich, zabaw andrzejkowych, noworocznych, karnawałowych, festynu w Boże Ciało itp.). Robotnicy pracujący przy rozbudowie przychodzą na imprezy masowe, jako tacy są rozpoznawani, ale nie zwracają uwagi swoim zachowaniem.

Wyraźnych, rozpoznawanych przez informatorów (miejscowych oraz robotników tymczasowo przebywających na terenie gminy) znaków różnic międzygrupowych jest dużo. Zauważa się na przykład różnice w zewnętrznym wyglądzie domów, zorganizowaniu przestrzeni domowej, wokół domów oraz intensywności prac wokół nich (charakterystyczne jest śląskie sprzątanie „swojego” kawałka ulicy). Wielu informatorów, przybliżając istotę różnic, używało określeń opar- 
tych na opozycji „śląski porządek - chadziajski bałagan” (do którego zaliczano np. „trzymanie gęsi na balkonach”, załatwianie się poza toaletą, „za ogrodzenie, przez płot"). Śląskie domy wyróżniają się pewnymi detalami, na przykład krótkimi firankami, kwiatkami na parapetach, które kojarzone są przez wielu informatorów z „niemieckością". To też te domy, które są zamieszkane przez osoby starsze lub domy całkiem opuszczone (charakterystycznym ich elementem maja być żaluzje antywłamaniowe) ze względu na fakt „pracy młodych w Niemczech”, którzy nie pozbywają się domów „na miejscu/tutaj”. Emigracja jest w ogóle na tym terenie zjawiskiem od dziesięcioleci dobrze oswojonym i z pewnością jeszcze do niedawna stanowiła wskaźnik różnicy (choćby przez fakt, iż wielu Ślązaków korzystało z możliwości swobodnego przemieszczania się między Polską a Niemcami na podstawie podwójnego obywatelstwa), obecnie jako taki wskaźnik działa pośrednio, właśnie poprzez funkcjonowanie miejscowych domów jako letnich przystani oraz przedsiębiorstw, które otwierane są dzięki funduszom pozyskanym $\mathrm{z}$ pracy zagranicą. W kontekście rozbudowy elektrowni ten wątek okazał się też znaczący - to głównie miejscowi mieli mieć pieniądze na urządzenie kwater dla napływających masowo pracowników.

Mieszkańcy gminy doskonale wiedzą, że przy rozbudowie oraz na terenie gminy pracują „Polacy, spółki mniejszości niemieckiej, spółki czeskie, Ukraińcy, Litwini”, ale pracownicy ci nie są częścią lokalnego życia. Ich obecność sprowadza się do zakupów w miejscowych dyskontach i życiu w miejscach zakwaterowania tak, iż wypowiedzi wielu informatorów można streścić w powtarzanym często zdaniu: „trudno mi cokolwiek powiedzieć na ich temat, oni trzymają się razem, my się trzymamy razem”, lub: „ich po prostu nie widać".

W tym kontekście przywoływana jest niekiedy fala osadnicza związana $\mathrm{z}$ budową elektrowni, kiedy to wybudowano osiedle dla pracowników budowy i elektrowni. Obecnie, na skutek zmian w systemie organizacji pracy na budowie, miejscowi uważają, że nieliczni, raczej z kadry zarządzającej, mogą na stałe osiedlić się w gminie. Robotnicy przybywają na krótko, wykonują specjalistyczne zadania i jadą wykonywać je gdzie indziej. Fakt organizacji pracy wymusza wręcz brak kontaktu między pracownikami rozbudowy a ludnością miejscową, co nie znaczy, że ich obecność nie jest przez jednostki negatywnie oceniana, głównie przez niedostosowanie się do miejscowych standardów życia codziennego (razi np. głośna muzyka wieczorami, gromadne przebywanie na podwórkach i głośne zachowania, niemówienie „dzień dobry”, „do widzenia”).

Pytania o kontakt z robotnikami wywołują kwestie stereotypów i autostereotypów. Te są na tyle trwałe, że pomimo podkreślania faktu zacierania się wyraźnych odrębnych tożsamości na terenie gminy, informatorzy bez trudu rekonstruują „cechy charakterystyczne innych”. Tak więc nie-Ślązacy o Ślązakach mówią, iż są przywiązani do miejsca, nieufni szczególnie w stosunku do nowo poznawanych ludzi, skryci, zamknięci w swoim gronie (na zamkniętość składa się także fakt wczesnowieczornego zamykania się $\mathrm{w}$ domach), niechętni do dzielenia się z in- 
nymi tym, co mają, „mający siebie za lepszych”, często niedouczeni, ale też pragmatyczni, ciężko i dobrze pracujący, lubiący porządek (ten wiąże się z ekologią, sortowaniem śmieci, „porządkiem niemieckim”), pomocni, gdy kogoś dobrze poznają, dobrze zorganizowani i ceniący praworządność. Z kolei miejscowi Ślązacy o Polakach mówią, że są niechętni do pracy, nie są przywiązani do utrzymania porządku, obojętni, nadużywający przekleństw, ale też chętni do pomocy, emocjonalni. Pragmatycznym wymiarem funkcjonowania różnic, zatem elementem pośrednio utrwalającym stereotyp, są na przykład kwestie kibicowania drużynom piłkarskim: Ślązacy - Niemcom, ludność napływowa - Polakom, widoczne różnice materialne, podział w sferze gospodarczej na zajęcia, w których specjalizują się głównie Ślązacy (zakłady produkcyjne i usługowe), co wynika z tego, że w rodzinach śląskich kładziony był od zawsze bardzo duży nacisk na naukę zawodu, kształcenie praktyczne tak, aby móc utrzymać rodzinę. Stosunek do małżeństw mieszanych też był różnicujący, choć nastawienie do nich zmienia się w ostatniej dekadzie. Panuje przekonanie, że Ślązacy preferowali małżeństwa w obrębie grupy śląskiej, natomiast Polacy nie mieli w tym zakresie preferencji. Obecność robotników tymczasowych nie jest postrzegana w kategoriach potencjalnego źródła nowych związków i małżeństw, jednak inaczej traktowano tych, którzy osiedlali się na stałe w związku z budową elektrowni.

Budowa elektrowni, która pojawia się w rozmowach na temat jej rozbudowy, była według informatorów także elementem wywołującym i później konserwującym różnice. Według niektórych realne zróżnicowanie ludności pojawiło się w związku z budową i nałożyło na fale emigracji Ślązaków na zachód. Początkowo obawiano się, że masowy przyjazd polskich pracowników na budowę wywoła na miejscu konflikty. Samą lokalizację obiektu traktowano jako element politycznej gry, mającej na celu osłabienie samodzielnego głosu ludności śląskiej/niemieckiej, „wymieszanie ludzi”, choć organizowano akcje promocyjne i informacyjne mające przekonać, iż elektrownia będzie miała pozytywny skutek, choćby w postaci pracy dla miejscowych. Młodzi nie postrzegali budowy jako zagrożenia, raczej jako szansę, ale pracę $\mathrm{w}$ elektrowni podjęło niewielu, między innymi $\mathrm{z}$ tego powodu, że „miejscowi się o to zatrudnienie nie starali, nie chcieli pracować w elektrowni”, z drugiej strony część osób właśnie z powodu niezatrudniania miejscowych uznaje, że ich oszukano.

Te same obawy, wzmocnione pamięcią wcale nieodległej czasowo budowy, rzutują na postrzeganie rozbudowy. Jednak ponownie obawy o wzrost przestępczości i wieczorne rozboje okazały się jak dotąd przedwczesne (choć według lokalnej policji obserwuje się nieznaczny wzrost liczby kradzieży). Informacja o rozbudowie elektrowni spotkała się z protestem, głównie ze strony osób, od których wykupywano domy i działki, ale perspektywa realnego polepszenia sytuacji wszystkich mieszkańców gminy ze względu na przyszłe wpływy do budżetu z tytułu obecności tak wielkiego zakładu oraz wzrost zatrudnienia w otoczeniu gospodarczym 
elektrowni spowodowały, że ostatecznie zaakceptowano rozbudowę. Hałas, zanieczyszczenie, degradację dróg ciężkim sprzętem przyjęto jako zło konieczne.

\section{Analiza i interpretacja wyników}

Z przytoczonych powyżej, skrótowo wskazanych, głównych wątków, wokół których buduje się miejscowe wyobrażenia i narracje o relacjach międzygrupowych, rozbudowa elektrowni oraz obecność dużej liczby robotników w rejonie wydają się rozłączne. Związane jest to niewątpliwie z dzisiejszą organizacją pracy przy tak wielkim przedsięwzięciu, gdzie rotacja firm wykonujących etapowe zadania jest duża, zatem nie ma stałej obecności kilku tysięcy pracowników na miejscu, jak zakładano, intensywność pracy jest ogromna, a wymagania w stosunku do pracowników budowy wysokie - potoczny obraz pijącego i awanturującego się robotnika, który stał się jednym z filarów obaw związanych z rozbudową, jest w tym miejscu błędny, nieprzystający do standardów kontroli stosowanych na tak wielkiej inwestycji. Elektrownia już po prostu jest i fakt jej rozbudowy, waloryzowany pozytywnie, nie jest umieszczany w planie miejscowych stosunków międzygrupowych. Niemniej materiał zgromadzony w czasie badań ujawnił dominujący skrypt związany z myśleniem o relacjach międzygrupowych, który w pewien sposób rzutował na postrzeganie pracowników i samej rozbudowy.

Warto w pierwszej kolejności odnotować fakt, że niezwykle celne i zaskakująco wciąż aktualne okazały się spostrzeżenia Stanisława Ossowskiego dotyczące więzi lokalnej, a konkretnie „swojskości”, jako podstawowego źródła tożsamości dla ludności autochtonicznej, oraz dychotomiczny podział na „swoich” i „nie-swoich” (miękka opozycja) obecny wśród wszystkich grup mieszkańców gminy. Potwierdzeniem tego jest niewyraźność i nieostrość kategorii etnicznych, za pomocą których, od momentu pojawiania się spisów powszechnych, próbuje się miejscową ludność klasyfikować. W przypadku, o którym sami mieszkańcy mówią, że jest pograniczny (odwołując się niekiedy do politycznie neutralnej i wyzutej z doraźności kategorii „łłowiańskości” jako właściwie ich identyfikującej, choć związanej z propagandą lat powojennych używającą tejże kategorii dla uzasadnienia rozszerzenia Polski na zachód, por. Linek 1998), tożsamość etniczna i przynależność narodowa są bardziej strategicznym wyborem niż silnie zinternalizowanymi i zintegrowanymi zbiorami postaw i wyobrażeń (por. Nycz 2010: 48; Simonides 2004: 158). Znakomicie widać to w planie historycznym, zresztą także celnie oddanym przez Ossowskiego, który pisząc o powojennych deklaracjach przynależności narodowej, zwracał uwagę, iż od tego, „czy ktoś został uznany za Polaka, czy nie, zależały losy jego i losy rodziny. Jakże tu się dziwić, że przez solidarność gromadzką ci, którym nie groziło wysiedlenie, usiłowali bronić patriotyzmu zagrożonych sąsiadów" (Ossowski 1947 [1984]: 84). Słuszność spostrzeżeń Ossowskiego potwierdza niedawna, solidarna reakcja mieszkańców gminy na administracyjne 
zmiany granic gminy, gdzie wobec konfliktu z narzucającą zmianę władzą centralną próba narzucenia sporowi charakteru etnicznego, że oto mniejszość niemiecka przeciwstawia się woli większości, spotkała się ze zdecydowanym odrzuceniem takiej klasyfikacji konfliktu, czego wyrazem było towarzyszące protestom hasło: „cała gmina zawsze razem”. Kolejnym znakiem potwierdzającym słuszność tez Ossowskiego jest sposób postrzegania i waloryzowania przez ludność miejscową zachowań nowych osadników, szczególnie w zakresie postaw i praktyk traktowanych jako materialne reprezentacje stanów świadomości - chodzi o akceptację i pozytywne postrzeganie „asymilacji”, „dostosowania się” ludności napływowej do lokalnych praktyk, czyli „zeswojszczenie”. Co więcej, ludność napływowa zinternalizowała lokalną gramatykę i także uważa, że reprodukcja lokalnego porządku jest pozytywnym elementem dokonujących się przemian, świadectwem zarysowującej się spójności społeczności lokalnej.

Na trwałość i siłę oddziaływania „swojskości” jako głównego korelatu tożsamości ma wpływ niewątpliwie, wciąż rejestrowane, poczucie historycznej krzywdy doznanej z każdej, „pozaswojskiej”, strony - od Niemców i Polaków. Na poczucie krzywdy składa się także poczucie dyskryminacji i wykluczenia Ślązaków z procesów decyzyjnych we własnej sprawie, na własnym terenie, a także delegitymizacja ich własnej tożsamości. Według Szmeji „poczucie zdominowania przez kulturę z zewnątrz, narzucenie obcych wzorów jest tak boleśnie odczuwane przez Ślązaków, że przyćmiewa pozostałe wymiary życia społecznego" (Szmeja 2000: 192; por. też Berlińska 1998b; Nowakowski 1957: 38). Po stronie ludności napływowej podobny skrypt dotyczy przesiedlonych „zza Buga” (czyli przesiedlonych z dawnych terenów Polski, które po drugiej wojnie światowej zostały wcielone do ZSRR), którzy przez długie lata odczuwali niepewność i tymczasowość zamieszkiwania pośród ludności rodzimej, co przekładało się między innymi na zauważalny przez miejscowych stosunek do materialnego otoczenia, jego zaniedbywanie, a także doświadczaną inność, a nawet w okresie tuż powojennym, wyższość nad autochtonami (Lis 2013: 66). Dla autochtonów było to potwierdzenie „gramatyczności” rozumienia sytuacji: są swoi i obcy, swojskość to znany porządek, obcość to „rzecz nie na miejscu”, jak sami przyjezdni, ludzie nie stąd i ich sposób życia („trzymanie kur na balkonach”, „bałagan w obejściach”). Przez ludność napływową to silne poczucie swojskości jest odbierane jako „izolacjonizm” Ślązaków, zamkniętość (streszcza to dobrze jedna $\mathrm{z}$ wypowiedzi: „dalej za próg nie wolno, tam jest na dziesięć spustów zamknięte”, choć pojęcie „zamkniętości” jest najczęściej przywoływaną charakterystyką różnicy między ludnością napływową a miejscowymi Ślązakami). Jednocześnie wszyscy informatorzy stwierdzali wzrost liczby małżeństw mieszanych w ostatnich latach, zanikanie oferty imprez dedykowanych mniejszości oraz ogólnie uwspólnianie życia publicznego (tu ogromną rolę odgrywają lokalne instytucje, takie jak np. gminny ośrodek kultury, straż pożarna, lokalne kluby sportowe, lokalne media oraz sam urząd gminy), z zachowaniem odrębno- 
ści w sferze prywatnej (np. obchodzeniem specyficznych świąt, z właściwym im lokalnym rytualizmem, czy używaniem gwary śląskiej w gronie rodzinnym).

Pracownicy rozbudowywanej elektrowni wyraźnie nie należą do wspólnej przestrzeni społecznej, a ponieważ to ona ma zasadniczy wpływ na lokalne relacje międzygrupowe, nie tylko nie mogą być częścią „swojskości”, ale też nie mogą być rozważani jako lokalni „aktorzy” posiadający jakąkolwiek moc sprawczą w zakresie regulacji stosunków miejscowych. Ich uczestnictwo w życiu lokalnej społeczności sprowadzające się do korzystania z lokalnych sklepów i noclegów, sporadycznych wizyt na otwartych imprezach czy nad jeziorkiem Balaton oraz brak zaangażowania w lokalne problemy jedynie potwierdzają słuszność takiej ich klasyfikacji przez ludność miejscową. W rozmowach używa się pojęcia „oni” na oznaczenie pracowników, w opozycji do wskaźników „my”/,tutaj” identyfikujących mieszkańców gminy. Deiktyczne wskaźniki różnicy w wypowiedziach wszystkich informatorów są bardzo częste, i to bez względu na to, czy rozmówcą jest osoba miejscowa, czy pracownik rozbudowy.

Chociaż, jak wspomniałem, wyraźnie widać, również z punktu widzenia informatorów, że w ostatnich latach zaczęła tworzyć się społeczność lokalna w gminie, to obecne są wciąż stereotypy wzajemne, które dają się sprowadzić do szeregu opozycji stanowiących ramę inferencji, uruchamianych szczególnie w sytuacjach konfliktu (jak się wydaje, jest to pewna stała socjologiczna dotycząca społeczności pogranicznych, por. Nycz 2010: 48). Tę ramę z punktu widzenia ludności nieśląskiej wyznaczają bieguny pojęć relatywnych: mniejszość niemiecka / uprzywilejowany / mający większe możliwości zarobkowania / zamożniejszy vs Polak / dyskryminowany / z mniejszymi możliwościami zarobkowania / biedniejszy (por. też: Berlińska 1998b). Jest obojętne, czy taka rama ma swój empiryczny grunt $\mathrm{w}$ miejscowych realiach, bowiem istnieje dla tych, którzy objęci byli badaniami w gminie. Co więcej, skoro - jak wcześniej ustalono - mamy na terenie gminy do czynienia z co najwyżej pewnymi „kategoriami etnicznymi”, to jedna z nich (mniejszość niemiecka, Ślązacy) postrzegana jest przez wielu informatorów nie-Ślązaków jako „sieć etniczna” (Handelman 1977: 194-196), czyli ukierunkowanie relacji miejscowych pod kątem etnicznym (preferencje przy zatrudnianiu, przetargach itp.). Ten wątek zanotowałem już podczas badań w 2006 roku, a więc można domniemywać, że jest stosunkowo trwałym elementem wzajemnych relacji. W drugą stronę stereotypizacja jest także obecna i ma jeden interesujący wymiar: w stosunku do ludności napływowej Ślązacy mają poczucie „aktywności/ ruchu”, że są tymi, którzy pracują, działają, „nie stoją w miejscu”, a napływowi są według informatorów mało aktywni, leniwi, czego charakterystycznym wyrazem miał być, przywoływany z nieodległej przeszłości lat 90., obraz „spacerujących z rękoma w kieszeniach" w dni wolne mieszkańców wybudowanego dla pracowników elektrowni osiedla „Energetyk”. Zatem w stosunku do zewnętrznych sił miejscowi Ślązacy pozbawieni są poczucia sprawczości, w stosunku do ludności napływowej jawią się jako siła sprawcza. Ten podwójny sposób widzenia siebie 
i siebie nawzajem utrwala się w początkach lat 90., kiedy lokalna władza przechodzi w ręce przedstawicieli ludności miejscowej (pragnienie sprawczości po stronie miejscowych wyrażane było wprost hasłami wyborczymi już w 1990 roku, a hasło brzmiało: „Nasze sprawy chcemy przejąć w swoje ręce”, Lis 2016: 123-124), zatem „sieć etniczna” zyskuje w oczach ludności napływowej realny wymiar. Stąd też staje się „winna” wielu rzeczom postrzeganym jako miejscowe patologie - od emigracji (czyli de facto nieumiejętności stworzenia miejsc pracy dla miejscowych), przez nierówne traktowanie poszczególnych miejscowości przy różnego rodzaju inwestycjach, po zainstalowanie przez młodsze pokolenie tablic dwujęzycznych, uważanych za zbędne mnożenie podziałów.

Niemniej od ponad dziesięciu lat następuje także proces stopniowego budowania poczucia wspólnoty lokalnej, umacniania się ładu społecznego, poczucia „my”/swojskości obejmującego także ludność napływową, poczucia opartego na współuczestnictwie $\mathrm{w}$ wielu formach zinstytucjonalizowanego życia na terenie gminy, sąsiedztwie, pomocy wzajemnej, małżeństwach mieszanych, które nie tylko oddolnie stanowią wyraźne znaki wspólnoty, ale to na te czynniki wskazują teorie dotyczące procesów tworzenia się społeczności lokalnych (por. np. Biernacka 1988; Marody 1986). To „my”, zdaniem wielu mieszkańców, umocniło się ostatnio pod wpływem politycznej batalii o zmianę granic miasta Opola. Batalia ujawniła też, że „etniczność” może być wciąż żywym elementem różnicującym, co więcej, gdy publicznie władze Opola i przedstawiciele rządu zaczęli używać argumentu różnicy etnicznej jako istotnej bariery w realizacji planu powiększenia Opola ${ }^{5}$, otwarcie na miejscu zaczęto mówić o faktycznej „cywilizacyjnej” odmienności tych, którzy stoją za planem poszerzenia Opola („Żydzi”, których reprezentuje według miejscowych prezydent Opola Arkadiusz Wiśniewski i „Cyganie”, których ma reprezentować Patryk Jaki, wywodzący się z Opola obecny sekretarz stanu w Ministerstwie Sprawiedliwości) - rozmowa, w czasie której usłyszałem taką interpretację sytuacji z ust osoby cieszącej się autorytetem, odbyła się w obecności kilku innych osób, które obserwując bacznie moją reakcję, potwierdziły te słowa.

Stereotypy wzajemne, odwołujące się jednak faktycznie do kryteriów pochodzenia miejscowego lub napływowego, nie zniknęły (por. Jonderko 1998: 152), ale w warunkach konfliktu gmina-Opole przestały potęgować różnice. Elektrownia i pracownicy rozbudowy, w czasie konfliktu, który jest dobrym momentem obserwacji stanu relacji społecznych i międzygrupowych, nie odgrywali roli podmiotu znaczącego. Badania nie potwierdziły zatem pierwszych intuicji i hipotez badawczych, które zgodnie $\mathrm{z}$ wnioskami z opracowań naukowych dotyczących społecznych skutków industrializacji (Czech 2009: 87) mogły sugerować, iż bę-

5 W tym kontekście liczne są, dostępne w domenie publicznej, wypowiedzi polityków, w szczególności opolskich, czy dziennikarzy, dotyczące „niemiecko-polskiego” sporu, wskazujące wprost na intencje pomysłodawców powiększenia Opola, którzy w ten sposób chcą zmarginalizować mniejszość niemiecką, pozbawić prawnych możliwości używania dwujęzycznych tablic miejscowości czy nauki języka niemieckiego jako pomocniczego w gminnych szkołach (por. Choroś, Skrabacz 2017). 
dziemy mieli do czynienia z pogłębieniem się napięć międzyetnicznych w związku z nagłą obecnością dużej liczby pracowników spoza regionu w miejscu o kruchej równowadze relacji etnicznych - kruchej już przed rozbudową elektrowni. Choć napięcia międzygrupowe są obserwowane, to na ich obecność i dynamikę fakt rozbudowy Elektrowni Opole nie ma wpływu.

\section{Bibliografia}

Barth F.

1969 Ethnic Groups and Boundries: The Social Organization of Culture Difference, London.

Berlińska D.

1995 Rola Elektrowni „Opole” w integracji społeczności lokalnej, „Śląsk Opolski”, 2.

1998a Uwagi o koncepcjach teoretycznych i założeniach metodologicznych badań, w: K. Frysztacki (red.), Polacy, Ślazacy, Niemcy. Studia nad stosunkami społeczno-kulturowymi na Śląsku Opolskim, Kraków, s. 17-32.

1998b Narodowo-etniczne stosunki międzygrupowe na Ślasku Opolskim. Ciągłość i zmiana, w: K. Frysztacki (red.), Polacy, Ślązacy, Niemcy. Studia nad stosunkami społeczno-kulturowymi na Śląsku Opolskim, Kraków, s. 33-74.

Biela A.

1993 Psychologiczne przesłanki strategii mediacyjnej w rozwiązywaniu konfliktu ekologicznego związanego z Elektrownia „Opole”, w: B. Łuszczewska (red.), Elektrownia „Opole” a środowisko społeczne, Opole, s. 171-179.

Biernacka J., Kunicka E. (red.)

2013 Ludność w województwie opolskim. Stan i struktura demograficzno-społeczna. Narodowy Spis Powszechny Ludności i Mieszkań 2011, Opole.

Biernacka M.

1988 Kulturowe przejawy więzi w społeczeństwach wiejskich, „Etnografia Polska”, t. 32, z. 1, s. 223-243.

Bloch M.

1998 How We Think They Think: Anthropological Approaches to Cognition, Memory, and Literacy, Boulder.

Choroś B., Skrabacz E.

2017 Mniejszość Niemiecka w prasie regionalnej w sytuacji konfliktu. Framing i agenda medialna w ramach sporu o „Duże Opole”, „Pogranicze: Polish Borderlands Studies”, t. 5, nr 3, s. 161-183.

Czech $\mathrm{H}$.

2009 Zmiana postrzegania Elektrowni Opole w województwie opolskim, w: C. Rosik-

-Dulewska, G. Kusz (red.), Budowa bloków 5 i 6 w PGE Elektrowni Opole SA - aspekty gospodarcze, środowiskowe i społeczne, Opole, s. 71-90.

Dolan C.S., Rajak D. (eds.)

2016 The Anthropology of Corporate Social Responsibility. New York.

Domański S.

1997 Problemy patologii społecznej w okresie trwania budowy Elektrowni „Opole” w latach 1984-1994 w gminie Dobrzeń Wielki, „Śląsk Opolski”, nr 1, s. 53-55. 
Douglas M.

1992 Risk and Blame: Essays in Cultural Theory, London-New York.

Frysztacki K. (red.)

1998 Polacy, Ślazacy, Niemcy. Studia nad stosunkami społeczno-kulturowymi na Ślasku Opolskim, Kraków.

Graeber D.

2015 Utopia regulaminów. O technologii, tępocie i ukrytych rozkoszach biurokracji, Warszawa.

Handelman D.

1977 The Organization of Ethnicity, „Ethnic Groups”, vol. 1 (3), s. 187-200.

Hann Ch., Hart K.

2015 Antropologia ekonomiczna. Historia, etnografia, krytyka, przeł. I. Kołbon, Poznań. Jonderko F.

1998 Stereotypy etniczne na Śląsu Opolskim. Czy generacyjna zmiana?, w: K. Frysztacki (red.), Polacy, Ślązacy, Niemcy. Studia nad stosunkami społeczno-kulturowymi na Śląsku Opolskim, Kraków, s. 149-170.

Kałuża R.

2003 Społeczno-ekonomiczne przeobrażenia ślaskiej gminy pod wpływem dużej inwestycji przemysłowej (na przykładzie gminy Dobrzeń Wielki i Elektrowni „Opole”), w: K. Frysztacki, K. Heffner (red.), W odpowiedzi na zjawiska i wyzwania społeczne, Opole, s. 383-384.

Kokot A.

1988 Przemiany społeczno-gospodarcze w gminie Dobrzeń Wielki pod wpływem intensywnej industrializacji, „Zeszyty Naukowe Wyższej Szkoły Inżynierskiej w Opolu”, nr 148 (Nauki Społeczne, z. 21), s. 155-166.

Linek B.

1998 Obraz mieszkańców Śląska Opolskiego na łamach prasy regionalnej: tożsamość grupowa, relacje międzygrupowe, modele wspótistnienia, w: K. Frysztacki (red.), Polacy, Ślązacy, Niemcy. Studia nad stosunkami społeczno-kulturowymi na Śląsku Opolskim, Kraków, s. 75-117.

Lis M.

2013 Śląsk Opolski w warunkach transformacji ustrojowej państwa od 1989 roku, Opole.

2016 Mniejszość niemiecka na Śląsku Opolskim 1989-2014. Z bagażem przeszłości w realiach wspótczesności, Opole.

Malarski S.

1995 Ewolucja zmian postaw społecznych i opinii wobec Elektrowni „Opole”, „Śląsk Opolski”, nr 2, s. 3-9.

Marody M.

1986 Warunki trwania i zmiany ładu społecznego $w$ relacji do stanu świadomości spoŁecznej, Warszawa.

Nowakowski S.

1957 Adaptacja ludności na Śląsku Opolskim, Poznań.

1960 Przeobrażenia społeczne wsi opolskiej, Poznań.

Nycz E.

2010 Współczesne identyfikacje mieszkańców pogranicza etniczno-kulturowego, „Śląsk Opolski”, nr 2-3, s. 47-60.

Olszewska A.

1969 Wieś uprzemysłowiona. Studium społeczności lokalnej w powiecie opolskim, Wrocław. 
Olszewska-Ładykowa A., Żygulski K.

1959 Małżeństwa mieszane na Śląku Opolskim, „Przegląd Socjologiczny”, t. 13, s. 89105.

Ossowski S.

1947 Zagadnienia więzi regionalnej i więzi narodowej na Śląku Opolskim, „Przegląd Socjologiczny”, t. 9, s. 73-124 (1984, w: S. Ossowski, O ojczyźnie i narodzie, Warszawa). Pękala J.

2001 Wypowiedź Józefa Pękali, prezesa Zarządu Elektrowni „Opole” SA, „Rzeczpospolita”, nr 296, 19 grudnia.

Rajak D.

2009 „I Am the Conscience of the Company”: Responsibility and the Gift in a Transnational Mining Corporation, w: K.E. Browne, L.B. Milgram (eds.), Economics and Morality. Anthropological Approaches, Lanham, s. 211-232.

Rauziński R.

1995 Społeczno-demograficzne problemy Dobrzenia Wielkiego w okresie budowy Elektrowni „Opole”, „Śląsk Opolski”, nr 2, s. 10-12.

Rosik-Dulewska C., Kusza G. (red.)

2009 Budowa bloków 5 i 6 w PGE Elektrowni Opole SA - aspekty gospodarcze, środowiskowe i społeczne, Opole.

Simonides D.

2004 Śląskie kłopoty z tożsamością, w: M.L. Nijakowski (red.), Nadciągaja Ślązacy. Czy istnieje narodowość śląska?, Warszawa, s. 157-164.

Sobek J.

1993 Antycypacja zdarzeń ekologicznych, społecznych i ekonomicznych w rejonie Elektrowni „Opole” przez mieszkańców gminy Dobrzeń Wielki w zależności od miejsca zatrudnienia, w: B. Łuszczewska (red.), Elektrownia „Opole” a środowisko społeczne, Opole, 146-155.

Sołdra-Gwiżdż T.

2009 Elektrownia „Opole” w świetle badań socjologicznych, w: C. Rosik-Dulewska, G. Kusz (red.), Budowa bloków 5 i 6 w PGE Elektrowni Opole SA - aspekty gospodarcze, środowiskowe i społeczne, Opole, s. 47-70.

2010 Socjologia wobec Śląska - jedność czy wielość?, Opole, 2010.

Szmeja M.

1988 Przemiany społeczności gminy Dobrzeń Wielki pod wpływem budowy elektrowni, „Zeszyty Naukowe Wyższej Szkoły Inżynierskiej w Opolu”, nr 148 (Nauki Społeczne, z. 21), s. 127-134.

1997 Starzy i nowi mieszkańcy Opolszczyzny, Opole.

2000 Niemcy? Polacy? Ślazacy! Rodzimi mieszkańcy Opolszczyzny w świetle analiz socjologicznych, Kraków.

Woźniacki J.

1988 System wartości mieszkańców Dobrzenia Wielkiego a postrzeganie budowy elektrowni i zmian przez nia wywołanych, „Zeszyty Naukowe Wyższej Szkoły Inżynierskiej w Opolu”, nr 148 (Nauki Społeczne, z. 21), s. 135-154. 